\title{
Modifiable risk factors for chronic non-communicable diseases among university students
}

\author{
Fatores de risco modificáveis para doenças crônicas não transmissíveis entre estudantes \\ universitários
}

Huana Carolina Cândido Morais ${ }^{1}$, Sara do Nascimento Cavalcante ${ }^{1}$, Leyliane Brito Nascimento ${ }^{1}$, Igor Cordeiro Mendes ${ }^{1}$, Karleandro Pereira do Nascimento ${ }^{1}$, Rafhael Fonseca ${ }^{1}$

Objective: to identify modifiable risk factors for chronic non-communicable diseases among university students. Methods: a cross-sectional study, carried out at a private university center in the countryside of Ceará, with 329 students, interviewed by averages of a questionnaire and analyzed by descriptive and inferential statistics. Results: predominantly students with an average age of 21 years, female (74.5\%), single (87.8\%) and income higher than three minimum wages. They had consumption of insufficient protective food and as well as harmful food. They did not practice physical activity (62.2\%), low consumption of tobacco (1.3\%) and high prevalence of alcoholism (37.8\%). Practices of physical activities, alcohol consumption and vegetables were significantly associated with sociodemographic and health data. Conclusion: modifiable risk factors for noncommunicable diseases were identified, making it necessary to articulate the health sector and the university in the implementation of health promotion strategies in educational institutions.

Descriptors: Noncommunicable Diseases; Risk Factors; Students; Nursing.

Objetivo: identificar fatores de risco modificáveis para doenças crônicas não transmissíveis entre estudantes universitários. Métodos: estudo transversal, realizado em Centro Universitário privado, no sertão central cearense, com 329 estudantes, entrevistados por meio de questionário e analisados por estatística descritiva e inferencial. Resultados: predominaram estudantes com mediana de 21 anos de idade, sexo feminino (74,5\%), solteiros $(87,8 \%)$ e renda superior a três salários mínimos. Consumo de alimentos protetores considerado insuficiente e de alimentos prejudiciais, adequado. Não praticavam atividade física (62,2\%), baixo consumo de tabaco $(1,3 \%)$ e alta prevalência de etilismo $(37,8 \%)$. Práticas de atividades físicas, etilismo e consumo de legumes/verduras estiveram associados significativamente com dados sociodemográficos e de saúde. Conclusão: foram identificados fatores de risco modificáveis para doenças não transmissíveis, tornando necessária articulação entre o setor saúde e a universidade, na implantação de estratégias de promoção à saúde em instituições de ensino.

Descritores: Doenças não Transmissíveis; Fatores de Risco; Estudantes; Enfermagem.

${ }^{1}$ Centro Universitário Católica de Quixadá. Quixadá, CE, Brazil. 


\section{Introduction}

With the processes of globalization and urbanization accelerated, Brazilians, like the world population, adopted a sedentary lifestyle, combined with the consumption of industrialized food, replacing homemade meals with food with excess calories, lipids, salt, sugars and preservatives. Besides these conditions, the frequent use of tobacco and alcohol contribute to the appearance of chronic non-communicable diseases, mainly in young people ${ }^{(1)}$.

Chronic non-communicable diseases are associated with several risk factors, such as dyslipidemia, overweight, physical inactivity, smoking, excessive alcohol consumption, hyperglycemia and poor intake of fruits and vegetables ${ }^{(2-3)}$. These conditions contribute to the emergence of diseases such as diabetes mellitus, hypertension, heart and cerebrovascular diseases, cancers and respiratory diseases, which represent the main causes of death in the world, corresponding to $63.0 \%^{(4)}$.

Another factor that contributes to the occurrence of non-communicable chronic diseases is physical inactivity, accompanied by the justifications of poor availability of time, motivation and fatigue, associated with the work day, even with the dissemination of the consequences of the lack of exercise in the media ${ }^{(5)}$.

For university students, they are considered risk factors for the development of non-communicable chronic diseases: change in routine and adaptation to the university world, use of social networks, exit of the parents' home and double journey for students that reconcile study and work. These conditions expose them to situations of health risk, especially with regard to food. The short time for meals and distance make college students prefer fast food at snack bars, fast food or restaurants, contributing to the consumption of unhealthy food ${ }^{(6)}$.

Currently, Brazil undergoes epidemiological changes in the national health-disease pattern, with a considerable increase in chronic diseases, among them, diabetes mellitus and hypertension correspond to a higher cause of mortality and hospital admissions, the global epidemic of overweight and obesity contribute to the incidence of chronic non-communicable diseases and increased health costs ${ }^{(7)}$.

Social determinants directly influence the incidence of chronic diseases, since social inequalities, differences in the acquisition of goods and services, level of schooling and access to information motivate the emergence of these diseases. This situation is aggravated in the Northern and Northeastern regions of Brazil, where the main hospitalizations due to chronic diseases are pneumonia, cardiovascular diseases and gastroenteritis ${ }^{(8)}$.

In view of this reality, in 2011 the Brazilian Department of Health launched the Strategic Action Plan for Coping with Chronic Non-communicable Diseases for the period 2011-2022, with the objective of promoting the creation and implementation of effective, sustainable integrated public policies and, with emphasis on the prevention, control and care of chronic non-communicable diseases and respective risk factors: smoking, physical inactivity, inadequate feeding and harmful use of alcohol ${ }^{(3,5)}$.

In this context, nurses can contribute to the reduction and control of chronic non-communicable diseases, through knowledge and adhesion to public health policies, through the implementation of actions that promote healthy life habits and awareness of the reduction of exposure to health factors, risk to the community, especially children and young people ${ }^{(9)}$.

Therefore, it was noticed the need to trace the situational diagnosis of risk factors for chronic non-communicable diseases in university students from the countryside of Ceará, in order to answer the questions: what is the prevalence of risk factors for chronic non-communicable diseases in this group? Is there an association between these risk factors and socioeconomic and health variables?

The present study aimed to identify modifiable risk factors for chronic non-communicable diseases among university students. 


\section{Methods}

Descriptive, exploratory and transversal study, carried out from August to September, 2016, in Private University Center, in the countryside of Ceará, Brazil. Students were selected from the health area (Nursing, Physiotherapy, Pharmacy, Biomedicine and Dentistry), totaling 1,198 students. A sample was calculated for finite population, which was stratified in the five health courses, according to the number of students enrolled.

329 university students of both sexes enrolled between the first and last period participated in the study. The invitation to participate in the research was done by the researcher before or after the class hours, with the authorization of the teacher responsible, and those who agreed to participate, signed the Term of Free and Informed Consent and answered the data collection questionnaire, characterizing the sampling for convenience. Students who were not in the room on the days of collection were excluded or were removed due to health certificate or medical leave.

Data collection was performed using a validated questionnaire, consisting of questions originating from the Brazilian Ministry of Health's instrument for surveillance of risk factors and protection for chronic diseases by telephone survey ${ }^{(10)}$. The questionnaire contained 44 multiple choice items, grouped into three categories: sociodemographic and economic data: sex, age, employment status, family income and marital status; anthropometric and health data: weight, height, health status, presence of diagnosed non-communicable chronic diseases and frequent use of medications; and lifestyle habits: physical activity practice, with frequency and duration, active or passive smoking, alcohol consumption, and eating habits.

For standardization of variables, recommendations were adopted by health agencies: it was considered appropriate to perform 30 minutes of moderate physical activity for a period of five days per week ${ }^{(11)}$; the daily consumption of at least one portion of beans, two fruits and three of vegetables was evaluated as adequate $^{(12)}$, as well as to remove skin or fat from the meat. For the consumption of soft drinks and sweets, it was considered inappropriate to ingest a portion for five or more days in the week ${ }^{(13)}$.

The data obtained were organized and analyzed by the Statistical Package for the Social Sciences, version 20.0, using descriptive statistical analysis, identifying the average, median, maximum and minimum values for quantitative variables, and absolute and relative frequencies for qualitative variables. For quantitative variables, the Kolmogorov-Smirnov test was applied to verify the adhesion of the data to the normal distribution. In the inferential analysis, the level of significance was set at $\mathrm{p}<0.05$. The Mann-Whitney tests were applied when the association between the quantitative variables and the risk factors was sought; and the Chi-square test, when the association was found between qualitative variables and risk factors. In addition, for the statistically significant associations between categorical variables, the odds ratio (OR) was calculated and the confidence intervals were presented.

The study complied with the formal requirements contained in the national and international regulations regulating research involving human beings, being submitted for ethical consideration (CAAE $57964016,8,0000,5046)$ and approved by the Ethics Committee (Protocol of Approval 1,658,477).

\section{Results}

Of the 329 students surveyed, the predominance was female $(74.5 \%)$, with an average age of 21 years ( $\mathrm{p}<0.001)$, who only studied $(81.3 \%)$, family income with an average of $R \$ 2,000(p<0.001)$, singles (87.8\%). In the majority, they considered themselves to be in good health (81.6\%) and the minority (13.7\%) had chronic non-communicable diseases diagnosed. Of these, the most prevalent were those of the respiratory, renal and cardiovascular tract.

The use of medications to control chronic disease, $61.7 \%$ used contraceptive medication and $32.0 \%$ 
of analgesic, anti-inflammatory or antipyretics. Regarding risk factors, the average body mass index $(24.2$ $\left.\mathrm{kg} / \mathrm{m}^{2}\right)$ showed a healthy weight $(\mathrm{p}=0.353)$, with medians of $1.64 \mathrm{~m}(\mathrm{p}<0.001)$ and average weight of 65.6 $\mathrm{kg}(\mathrm{p}=0.025)$. Socio-demographic, economic and health data are presented in Table 1.

Table 1 - Sociodemographic, economic and clinical characterization of the students surveyed

\begin{tabular}{lc}
\hline Variables & n (\%) \\
\hline Sex (n=329) & $245(74.5)$ \\
Female & $84(25.5)$ \\
$\quad$ Male & \\
Work status (n=326) & $265(81.3)$ \\
$\quad$ Study only & $61(18.7)$ \\
$\quad$ Study and work & \\
Marital status (n=329) & $40(12.2)$ \\
$\quad$ Married / stable union & $289(87.8)$ \\
Single / Divorce & \\
health status (n=326) & $266(81.6)$ \\
Good & $60(18.4)$ \\
Regular & \\
Frequency of chronic diseases (n=322) & $44(13.7)$ \\
Yes & $278(86.3)$ \\
No & \\
Use of medication with frequency (n=324) & $162(50.0)$ \\
Yes & $162(50.0)$ \\
No &
\end{tabular}

Only $37.8 \%$ of the students practiced physical activity, considering the physical activity pattern of those who affirmed to perform (92.1\%) and spent 30 minutes or more exercising, and $66.3 \%$ performed activities at least three times in the week. Active and passive smoking was little observed, $13.1 \%$ and $1.3 \%$, respectively.

The consumption of beans (35.1\%), fruits (16.4\%), vegetables or vegetables $(22.5 \%)$ was present; however, they were not consumed in the adequate quantity. Despite being reported by the participants, the consumption of harmful food was considered adequate, especially of soft drinks and artificial juice (89.5\%). Data on the practice of physical activity, alcoholism, smoking and food consumption are shown in Table 2.
Table 2 - Modifiable risk factors for non-transmissible chronic diseases

\begin{tabular}{lc}
\hline Variables & n (\%) \\
\hline Physical activity practice & $123(37.3)$ \\
Active smoking & $4(1.2)$ \\
Passive smoker & $40(12.1)$ \\
Alcoholism & $121(36.7)$ \\
Adequate consumption of protective foods & \\
Beans & $114(35.1)$ \\
Greenery or vegetables & $73(22.5)$ \\
Fruit & $53(16.4)$ \\
Proper consumption of harmful food & \\
Meat without skin or fat & $254(78.1)$ \\
Soda or artificial juice & $291(89.5)$ \\
Sweets & $251(77.2)$ \\
\hline
\end{tabular}

Some modifiable risk factors presented a statistically significant association with only one variable: fruit consumption with labor situation $(\mathrm{p}=0.048)$; consumption of meat with skin or fat $(p=0.044)$; and consumption of sweets with the use of frequent medications $(\mathrm{p}=0.028)$.

The performance of physical activities had a statistically significant association with gender $(\mathrm{p}=0.003)$, weight $(\mathrm{p}=0.009)$ and height $(\mathrm{p}=0.035)$. In addition, we identified a statistically significant association between the variables alcohol and sex $(\mathrm{p}=0.004)$, marital status $(\mathrm{p}=0.013)$, family income $(\mathrm{p}=0.001)$, weight. Regarding the consumption of protective food, a statistically significant association was observed between bean consumption and frequent medication use ( $\mathrm{p}=0.028)$; and consumption of vegetables with sex $(p=0.007)$, age $(p=0.023)$, weight $(\mathrm{p}=0.015)$ and height $(\mathrm{p}=0.007)$ also obtained a statistically significant association.

Regarding the statistical analysis, the association between sociodemographic, economic and health variables with modifiable risk factors was evaluated, according to Table 3. 
Table 3 - Inferential analysis with sociodemographic, economic and health data and modifiable risk factors of the students surveyed

\begin{tabular}{|c|c|c|c|c|}
\hline Variables & $\begin{array}{c}\text { Physical } \\
\text { activity } \\
\text { practice }\end{array}$ & $\begin{array}{l}\text { Alcoho- } \\
\text { lism }\end{array}$ & $\begin{array}{l}\text { Bean con- } \\
\text { sumption }\end{array}$ & $\begin{array}{c}\text { Consumption } \\
\text { of greens and } \\
\text { vegetables }\end{array}$ \\
\hline Sex & $0.003^{*}$ & $0.004^{*}$ & $0.053^{*}$ & $0.007^{*}$ \\
\hline Work status & $0.346^{*}$ & $0.248^{*}$ & $0.777^{*}$ & $0.188^{*}$ \\
\hline Marital status & $0.601^{*}$ & $0.013^{*}$ & $0.486^{*}$ & $0.681^{*}$ \\
\hline Having chronic illness & $0.975^{*}$ & $0.430^{*}$ & $0.556^{*}$ & $0.107^{*}$ \\
\hline $\begin{array}{l}\text { Use of frequent medi- } \\
\text { cation }\end{array}$ & $0.089 *$ & $0.151^{*}$ & $0.028^{*}$ & $0.940^{*}$ \\
\hline Age & $0.217^{* *}$ & $0.131^{* *}$ & $0.756^{* *}$ & $0.023^{* *}$ \\
\hline Family income & $0.292^{* *}$ & $0.001^{* *}$ & $0.080^{* *}$ & $0.654^{* *}$ \\
\hline Weight & $0.009^{* *}$ & $0.025^{* *}$ & $0.063^{* *}$ & $0.015^{* *}$ \\
\hline Height & $0.035^{* *}$ & $0.030^{* *}$ & $0.098^{* *}$ & $0.007^{* *}$ \\
\hline
\end{tabular}

For the statistically significant associations, the following odds rations and confidence intervals were calculated: adequate fruit consumption and labor status OR=0.580 (CI: 0.342-0.983); physical activity and sex OR=0.433 (CI: 0.247-0.761); ethnicity and sex OR=0.476 (CI: 0.284-0.795); ethnicity and marital status OR=0.369 (CI: 0.164-0.831); adequate consumption of beans and use of frequent medications $\mathrm{OR}=0.596$ (CI: 0.375-0.948); adequate consumption of vegetables or vegetables with sex $\mathrm{OR}=0.465$ (CI: 0.265-0.815).

\section{Discussion}

The limitations of the study were considered the type of instrument chosen, and it was not possible to verify the reliability of the information provided. Also, the restriction of data collection to a single institution, limited the generalization of the presented results. These data provide theoretical support and suggest new studies for the planning of health promotion strategies in educational institutions related to the risk factors for chronic non-communicable diseases, which support the link between the health sector and the university as modifiers of the users.

In line with the results of the research, data from the Brazilian Census of Higher Education, conducted in 2013, with 2,391 educational institutions, show that the majority of those enrolled in higher education were female ${ }^{(14)}$, even in those courses where the male sex, such as Medicine and Dentistry, prevailed. In addition, in the present study, $81.3 \%$ of the participants only studied, having to depend on the family income.

Approximately $13.7 \%$ of the participants stated that they had a medical diagnosis of non-transmissible chronic disease, even with the high number of risk factors they were subjected to, which could indicate a lack of knowledge about the diagnosis of these diseases. A similar study was observed in 351 young adults from the State of Ceará, Brazil, in which 1.2\% of the participants had hypertension and $0.6 \%$ diabetes mellitus, but $50.4 \%$ were not aware of hypertension and $64.0 \%$ were ignorant of being diabetic and, consequently, the incidence of risk factors was high, since they presented a family history for chronic non-communicable diseases ${ }^{(15)}$.

A study of 154 students from the University of Aveiro, Portugal, analyzed socio-demographic and behavioral characteristics, as well as anthropometric and health data for two years, identifying the average risk for the development of chronic non-communicable diseases in both sexes. Women had high average values of lipids and men had higher levels of glucose, body mass index and blood pressure ${ }^{(16)}$. In the present study, being a woman was associated with the practice of physical activity, lower alcohol consumption and adequate intake of fruits and vegetables, which corresponds to protective behaviors against the development of chronic non-communicable diseases.

The medication class most used by the participants was contraceptive $(61.7 \%)$, which requires attention, since the use of oral contraceptives, combined with other risk factors for chronic non-communicable diseases, increases the chances for early development of stroke in women of childbearing age ${ }^{(17)}$. 
In addition, some medications have body weight gain, such as psychotropic drugs, anti-diabetics and hormonal medications (e.g. corticosteroids and medroxyprogesterone $)^{(18)}$. Currently, there is an increase in overweight and obesity in the adult population in Brazil. In a study of 464 adults aged 20 to 59 years, it was observed that $23.2 \%$ of the women and $30.9 \%$ of the men aged 20 to 29 years had a Body Mass Index above $25 \mathrm{~kg} / \mathrm{m}^{2}$, of weight ${ }^{(19)}$. However, in the present study, the calculated average Body Mass Index was equivalent to an adequate nutritional status, differing from the national trend.

The importance of practicing physical activity for improving health is undeniable. However, as the frequency of this practice is increasing, sedentarism still presents alarming numbers. In longitudinal research $^{(16)}$, carried out with university students, it was evidenced that individuals exposed to academic life have higher rates of dyslipidemia and overweight, when compared with freshmen, however, a sedentarism rate of $80.0 \%$ was observed, groups studied in the research.

In accordance with this, national research shows that $48.7 \%$ of adults did not have a satisfactory level of physical activity, and considering gender, women represented the majority of this value ${ }^{(10)}$. In the present study, the frequency of sedentarism corresponded to the national standard. The low incidence of physical activity is usually justified by the limited availability of time, since health science courses are full-time ${ }^{(9)}$.

It is worth noting that tobacco consumption has been decreasing over the years in Brazil, being less frequent among the young population. In a population-based study, it was found that $10.8 \%$ of the adults surveyed smoked. These data show that the frequency of smokers under 25 years of age is decreasing in the country ${ }^{(10)}$. In agreement with the aforementioned studies, this research demonstrated that smoking among students is low.

When referring to alcoholism, the situation is contrary to the previous one, since the consumption is more frequent both by men and women, mainly in young adults. In a study, the frequency of consumption was $76.1 \%$ among young adults( ${ }^{(15)}$, being high in both sexes, male $(96.6 \%)$ and female $(97.1 \%)^{(20)}$.

The consumption of protective food is important for replenishing vitamin, protein and mineral nutrients necessary for the human body. According to the national telephone survey, the frequency of bean consumption for five or more days of the week was cited by $66.1 \%$ of the respondents, being higher among males, tending to increase in the age group of 18 to 24 years. Regular consumption of fruits and vegetables was $36.5 \%$, being higher among women (42.5\%), increasing with age and schooling above 12 years for both $\operatorname{sexes}^{(10)}$. In the present study, a correlation between protective food consumption and female work status was identified, based on the identification of higher consumption of fruits and vegetables by women and university students who only studied.

Regarding the intake of harmful food, according to data from the Brazilian Health Survey, consumption of meat with excess fat was reported by $37.2 \%$ of the sample, prevailing in males and in persons aged 25 to 39 years $^{(13)}$. Accordingly, data from the national survey show that $29.4 \%$ of people reported consuming meat with excess fat, being higher among men than in women $^{(10)}$.

In addition, the Ministry of Health of Brazil recommends that the consumption of soft drinks, juices, sweet and stuffed biscuits, cakes and industrialized delicacies be avoided. In the Brazilian population, consumption of soft drinks on five or more days in the week was reported by $20.8 \%$ of the participants, also being larger among males, decreasing with increasing age ${ }^{(10)}$. While the consumption of sweets, in studies, prevailed in young and with a higher degree of education $^{(10,13)}$. In this study, the consumption of harmful food was considered adequate by most of the university students participating in the research. It should be noted that the values adopted for adequate consumption of harmful food are not standardized in the studies mentioned above. 


\section{Conclusion}

Modifiable risk factors for non-communicable diseases were identified, making it necessary to articulate the health and university sectors in the implementation of health promotion strategies in educational institutions.

\section{Collaborations}

Morais HCC, Cavalcante SN and Nascimento LB collaborated in the design of the project. Mendes IC assisted in the analysis and interpretation of the data. Nascimento KP and Fonseca R contributed in the writing of the article. All authors cooperated with the critical review of the intellectual content and final approval of the version to be published.

\section{References}

1. Malta DC, Silva Jr JB. O Plano de Ações Estratégicas para o Enfrentamento das Doenças Crônicas Não Transmissíveis no Brasil e a definição das metas globais para o enfrentamento dessas doenças até 2025: uma revisão. Epidemiol Serv Saúde. 2013; 22(1):151-64. doi: http://dx.doi.org/10.5123/ S1679-49742013000100016

2. Rombaldi AJ, Silva MC, Dumith SC, Viana VR, Hallal PC. Fatores de risco para doenças crônicas não transmissíveis em estudantes de educação física ingressantes e formandos. Rev Bras Ciênc Esporte. 2014; 36(1):13-27. doi: http://dx.doi. org/10.1590/S0101-32892014000100002

3. Bernardes LE, Vieira EES, Lima LHO, Carvalho GCN, Silva ARV. Risk factors for chronic noncommunicable diseases in university students. Cienc Cuid Saúde. 2015; 14(2):1122-228. doi: http:// dx.doi.org/10.4025/cienccuidsaude.v14i2.22517

4. World Health Organization. Chronic diseases [Internet]. 2016 [cited 2018 Apr. 13]. Available from:http://www.who.int/cardiovascular_ diseases/15032013_updated_revised_draft_ action_plan_spanish.pdf?ua=1
5. Lima ACS, Araújo MFM, Freitas RWJF, Zanetti ML, Almeida PC, Damasceno MMC. Risk factors for type 2 diabetes mellitus in college students: association with sociodemographic variables. Rev Latino-Am Enfermagem. 2014; 22(3):484-90. doi: http:// dx.doi.org/10.1590/0104-1169.3053.2441

6. Ramalho AA, Dalamaria T, Souza OF. Consumo regular de frutas e hortaliças por estudantes universitários em Rio Branco, Acre, Brasil: prevalência e fatores associados. Cad Saúde Pública. 2012; 28(7):1405-13. doi: http://dx.doi. org/10.1590/S0102-311X2012000700018

7. Bahia LR, Araújo DV. Impacto econômico da obesidade no Brasil. Rev HUPE. 2014; 13(1):13-7. doi: http://dx.doi.org/10.12957/rhupe.2014.9793

8. Pereira FJR, Silva CC, Lima Neto EA. Perfil das Internações por Condições Sensíveis à Atenção Primária subsidiando ações de saúde nas regiões brasileiras. Saúde Debate. 2015; 40(107):100817.doi:http://dx.doi.org/10.1590/0103110420161070142

9. Santos LR, Brito ECC, Lira Neto JCG, Alves LEP, Alves LRA, Freitas RWJF. Análise do sedentarismo em estudantes universitários. Rev Enferm UERJ [Internet]. 2014 [citado 2018 mai 03]; 22(3):41621. Disponível em: http://www.e-publicacoes. uerj.br/index.php/enfermagemuerj/article/ view/13768/10513

10. Malta DC, Stopa SR, Iser BPM, Bernal RTI, Claro RM, Nardi ACF, et al. Risk and protective factors for chronic diseases by telephone survey in capitals of Brasil, Vigitel 2014. Rev Bras Epidemiol. 2015; 18(Suppl 2):238-55. doi: http://dx.doi. org/10.1590/1980-5497201500060021

11. Mielke GI, Hallal PC, Rodrigues GBA, Szwarcwald CL, Malta DC. Prática de atividade física e hábito de assistir à televisão entre adultos no Brasil: Pesquisa Nacional de Saúde 2013. Epidemiol Serv Saúde. 2015; 24(2):277-86. doi: http://dx.doi. org/10.5123/S1679-49742015000200010

12. Jaime PC, Stopa SR, Oliveira TP, Vieira ML, Szwarcwald CL, Malta DC. Prevalence and sociodemographic distribution of healthy eating markers, National Health Survey, Brazil, 2013. Epidemiol Serv Saúde. 2015; 24(2):267-76. doi: http://dx. doi.org/10.5123/S1679-49742015000200009 
13. Claro RM, Santos MAS, Oliveira TP, Pereira CA, Szwarcwald AL. Unhealthy food consumption related to chronic non-communicable diseases in Brazil: National Health Survey, 2013. Epidemiol ServSaúde. 2015; 24(2):257-65.doi:http://dx.doi. org/10.5123/S1679-49742015000200008

14. Instituto Nacional de Estudos e Pesquisas Educacionais Anísio Teixeira (INEP). Censo da educação superior 2013: resumo técnico. Brasília: INEP; 2015.

15. Gomes EB, Moreira TMM, Pereira HCV, Sales IB, Lima FET, Freitas CHA, Rodrigues DP. Fatores de risco cardiovascular em adultos jovens de um município do Nordeste brasileiro. Rev Bras Enferm. 2012; 65(4):594-600. doi: http://dx.doi. org/10.1590/S0034-71672012000400007

16. Brandão MP, Pimentel FL, Cardoso MF. Impact of academic exposure on health status of university students. Rev Saúde Pública. 2011; 45(1):4958. doi: http://dx.doi.org/10.1590/S003489102011000100006
17. Ryan KA, Cole JW, Saslow K, Mitchell BD, Mcardle PF, Sparks MJ, et al. Prevention opportunities for oral contraceptive-associated ischemic stroke. Stroke. 2014; 45:893-5. doi: http://dx.doi. org/10.1161/STROKEAHA.113.004023

18. Sousa LAO, Fonteles MMS, Monteiro MP, Mengue SS, Bertoldi AD, Pizzol TSD, et al. Prevalence and characteristics of adverse drug events in Brazil. Cad Saúde Pública. 2018; 34(4):e00040017. doi: http://dx.doi.org/10.1590/0102-311X00040017

19. Holanda LGM, Martins MCC, Souza Filho MD, Carvalho CMRG, Assis RC, Leal LMM, et al. Overweight and abdominal in adult population of Teresina, PI. Rev Assoc Med Bras. 2011; 57(1):50-5. doi: https://doi.org/10.1016/S22554823(11)70016-9

20. Pilatti A, Read JP, Pautassi RM. ELSA 2016 Cohort: alcohol, tobacco, and marijuana use and their association with age of drug use onset, risk perception, and social norms in Argentinean College Freshmen. Front Psychol. 2017; 8:1452. doi: http://dx.doi.org/10.3389/ fpsyg.2017.01452 